\title{
Rifampin hypersensitivity in a two year-old child with successful rapid oral desensitization
}

\author{
KJ Hildebrand*, D Hummel \\ From Canadian Society of Allergy and Clinical Immunology Annual Scientific Meeting 2009 \\ Halifax, Canada. 22-25 October 2009
}

A two year, 10 month-old child was referred to a tertiary allergy clinic following an adverse reaction to rifampin. Her mother had isoniazid-resistant pulmonary tuberculosis. The child was born in Canada, was asymptomatic, had a normal chest $\mathrm{x}$-ray and liver enzymes. Mantoux induration was $17 \mathrm{~mm}$. The child was prescribed oral rifampin, $150 \mathrm{mg}$ per day for 3 months. Thirty minutes after ingesting the fifth dose, she developed swelling of the lips, eyes and face; and a pruritic rash to the extremities and face. Anti-histamine was administered: the rash resolved over thirty minutes and facial swelling over 2-3 hours. There were no other IgEmediated symptoms. Rifampin was discontinued. Past history was negative for atopy, adverse drug reactions, and food allergies.

Intravenous rifampin $(600 \mathrm{mg} / \mathrm{mL})$ was used for skin prick and intradermal testing. The patient was admitted to hospital and intravenous access established. Skin prick test results were negative to undiluted rifampin and saline; the histamine response was positive $(5 \mathrm{~mm})$. Intradermal testing was performed at 15-minute intervals with dilutions of 1:10,000, 1:1000 and 1:100. The 1:100 dilution test was positive.

Rapid desensitization to oral rifampin was performed over 3.25 hours. The first dose was $1 / 10,000$ of the total dose. Thirteen incremental doses were administered every 15 minutes until a cumulative dose of $151.08 \mathrm{mg}$ had been ingested (Table 1). No adverse events were noted. The child was subsequently continued on a dose of oral rifampin $75 \mathrm{mg}$ twice daily and has not had subsequent reactions.

This case highlights the rare occurrence of rifampin hypersensitivity in a child. Desensitization was motivated by the lack of alternative therapies. Rifampin desensitization protocols preciously reported have occurred

\footnotetext{
Division of allergy and clinical Immunology at the Hospital for Sick Children
} and the University of Toronto, Canada predominantly in the adult population over several days. We describe a case of rapid oral desensitization to rifampin in a two year-old child.

Published: 12 May 2010

\section{doi:10.1186/1710-1492-6-S1-P22}

Cite this article as: Hildebrand and Hummel: Rifampin hypersensitivity in a two year-old child with successful rapid oral desensitization. Allergy, Asthma \& Clinical Immunology 2010 6(Suppl 1):P22.

\section{Submit your next manuscript to BioMed Central and take full advantage of: \\ - Convenient online submission \\ - Thorough peer review \\ - No space constraints or color figure charges \\ - Immediate publication on acceptance \\ - Inclusion in PubMed, CAS, Scopus and Google Scholar \\ - Research which is freely available for redistribution \\ Submit your manuscript at www.biomedcentral.com/submit}

